\title{
非染色で非追跡の拡散係数場評価法による 核生成前の結晶化現象の可視化 \\ Visualization of crystallization before nucleation by evaluation of diffusion coefficient field without labeling or tracking
}

\author{
○正 花崎 逸雄 ${ }^{* 1}$, 岡野 和希 ${ }^{* 2,3}$ \\ 吉川 洋史 ${ }^{* 2}$, 杉山 輝樹 ${ }^{* 3, * 4}$ \\ Itsuo HANASAKI ${ }^{* 1}$, Kazuki OKANO ${ }^{* 2, * 3}$, \\ Hiroshi Y. YOSHIKAWA ${ }^{* 2}$, and Teruki SUGIYAMA ${ }^{* 3, * 4}$ \\ *1 東京農工大学 Tokyo University of Agriculture and Technology \\ *2 埼玉大学 Saitama University \\ *3 台湾国立交通大学 NCTU \\ *4 奈良先端科学技術大学院大学 NAIST
}

Key Words : Particle Image Diffusometry, Crystallization, Nucleation, Diffusion, Visualization

機械工学の流体工学分野では，実験計測で獲得した動画データから流体の速度場を定量評価する 2 系統の手法 が長年に渡り追究されてきた。それらは，Particle Tracking Velocimetry (PTV)と Particle Image Velocimetry (PIV) と呼 ばれている. PTVでは，時系列撮影像である動画から，トレーサーとして機能する粒子像を追跡する. 追跡した 軌跡を時間・空間的に平均すれば，流速ベクトルが求まる。一方，PIVでは，ある時刻の画像を ROI（Region Of Interest）に分割し，次の撮影時刻で得られた画像で各 ROI が最もどこに相関が高いのかを評価する方法が一般的 である。いずれの場合も，連続体力学の描像に基づいて，滑らかな速度場を評価することが目的である．顕微鏡 に実装したカメラで撮影した動画でPTV を行う場合, 粒子は微小であるため Brown 運動している.このランダ ムな運動は，速度場の評価を目的とする場面では，ノイズとみなされてきた。しかし，微小なスケールの輸送現 象では，流れと拡散が共存しているのが一般的な姿であり，Brown 運動は外乱ではない．PTV と直接関連する技 術として，生物学や医学や農学などバイオ系の分野では, Single Particle/Molecule Tracking (SPT/SMT) と呼ばれる 技術が長年活用されてきた. 分子や光の波長より小さいナノ粒子は一般的な光学顕微鏡で直接観測できないので, 昔から細胞や組織上にある特定の生体分子に結合させて輝点として観測できるようにする蛍光分子の開発が盛ん であった．輝点を追跡して獲得した軌跡群からは，指向性のある輸送と共に，平均二乗変位の時間に対する変化 に基づく拡散係数の評価が行われてきた．細胞内外や細胞膜，あるいは，一般にソフトマターと呼ばれるような 物質では，そのレオロジ一特性を評価する上で，粘度とも関連深い拡散係数を評価することも重要である．例え ば，溶液中に漂う溶質分子群から核生成して結晶が現れる現象は，製薬における薬剤分子の機能発現を決定づけ る. 核生成の前に何が起きているのか知ることは基礎と応用の両面から重要だが，蛍光染色すると結晶化現象自 体に影響を与えてしまう場合もある，粒子追跡に基づく PTVのように，拡散挙動の評価としては SPT/SMTがあ る.これとは対照的に，PIVのように輝点を追跡せずに拡散係数の場を評価する方法は長年存在しなかった．著 者の一人は近年 Particle Image Diffusometry (PID)を発明し(1)，わかりやすい系で機能を例示した(2). 本講演では, 産 業上も基礎科学上も重要な対象である, 結晶核生成前の溶質分子群挙動に PID を応用した事例を議論する(3).

\section{文献}

（1）花崎逸雄，“微粒子情報解析装置、微粒子情報解析方法及び微粒子情報解析プログラム”, 出願番号 : 2016-211838, 公開番号：特開 2018-07241（出願日：2016年 10 月 28 日，公開日：2018 年 05 月 10 日）.

(2) Hanasaki, I., and Ooi, Y., "Particle image diffusometry: Resolving diffusion coefficient field from microscopy movie data without particle tracking”, AIP Advances, Vol.8, (2018), 065014 (6 pages).

(3) Hanasaki, I., Okano, K., Yoshikawa, H.Y., and Sugiyama, T., "Spatiotemporal dynamics of laser-induced molecular crystal precursors visualized by particle image diffusometry", The Journal of Physical Chemistry Letters, Vol.10, (2019), pp.7452-7457. 